\title{
Cannabinoid Hyperemesis Syndrome: A Case Report of an Underdiagnosed Condition
}

\author{
João Machado Nogueira Inês Fonseca Marco Duarte \\ Departamento de Psiquiatria e Saúde Mental, Centro Hospitalar de Setúbal, Setúbal, Portugal
}

\author{
Keywords \\ Cannabis · Cannabinoid · Hyperemesis - Cyclic vomiting . \\ Case report
}

\section{Abstract}

Cannabinoid hyperemesis syndrome (CHS) is characterized by episodic bursts of nausea, vomiting and abdominal pain, affecting chronic cannabis users. The clinical picture mimics an acute abdomen, usually leading to multiple assessments in the emergency department. Several complementary diagnostic examinations are performed with non-specific results, making differential diagnosis puzzling. We present a case of a 42-year-old man, who has been admitted multiple times to the emergency department in the last 3 months for abdominal pain, nausea and vomiting, without triggering factors and improving only with hot water baths. He was evaluated by different specialties, the various complementary diagnostic tests performed showed no significant results, and no definitive diagnosis was obtained. Treatment resulted only in a partial and transient resolution of symptoms. A more detailed medical history revealed cannabis use for more than 5 years, with a recent increase in the amount consumed. After psychoeducation, explaining the risks associated with con-

João Machado Nogueira and Inês Fonseca contributed equally to this work.

karger@karger.com www.karger.com/pjg

Karger $\stackrel{\text { ' }}{5}$

BOPEN ACCESS (c) 2020 Sociedade Portuguesa de Gastrenterologia Published by S. Karger AG, Basel

This is an Open Access article licensed under the Creative Commons Attribution-NonCommercial-4.0 International License (CC BY-NC) (http://www.karger.com/Services/OpenAccessLicense), applicable to the online version of the article only. Usage and distribution for commercial purposes requires written permission. sumption and its relationship with the clinical symptoms, which resulted in complete suspension of cannabis, there have been no new symptomatic episodes since then. We present an illustrative case of a poorly reported clinical entity despite having a probable significant prevalence, raising awareness in order that clinicians identify and properly manage these cases.

(c) 2020 Sociedade Portuguesa de Gastrenterologia Published by S. Karger AG, Basel

\section{Síndrome hiperemética dos Canabinóides: um caso clínico de uma patologia subdiagnosticada}

Palavras Chave

Cannabis · Canabinóides · Hiperémese · Vómitos cíclicos . Caso-clínico

\section{Resumo}

A Síndrome Hiperemética dos Canabinóides cursa com crises episódicas de náuseas, vómitos e dor abdominal que acometem consumidores crónicos de cannabis. 0 quadro clínico mimetiza o de um abdómen agudo, condicionando habitualmente múltiplas avaliações no Serviço de Urgência (SU) que levam à realização de vários exames complementares de diagnóstico (ECD), cujos resultados 
tendem a ser inespecíficos, dificultando o diagnóstico diferencial. Apresentamos o caso de um homem de 42 anos de idade, sem antecedentes psiquiátricos conhecidos, que nos últimos 3 meses foi admitido por múltiplas vezes no SU Hospitalar por dor abdominal, náuseas e vómitos aliviados com banhos de água quente. Vários exames auxiliares de diagnóstico e avaliação por diferentes especialidades foram realizados, sem que se obtivesse um diagnóstico definitivo. A terapêutica sintomática instituída resultou apenas numa resolução parcial e transitória dos sintomas. Uma história clínica mais detalhada revelou um consumo de cannabis há mais de 5 anos, com incremento recente da quantidade consumida. Após psicoeducação ao doente, explicando os riscos do consumo de canabinóides e a sua relação com a sintomatologia apresentada resultou na suspensão completa no consumo de cannabis, não se tendo verificado novos episódios sintomáticos desde então. Este é um caso ilustrativo de uma entidade clínica recente, cuja prevalência está a aumentar, tendo em conta o aumento do consumo de cannabis. A adequada identificação desta patologia é fundamental para um tratamento adequado e eficaz, evitando o uso desnecessário de métodos complementares de diagnóstico e medicação.

() 2020 Sociedade Portuguesa de Gastrenterologia Publicado por S. Karger AG, Basel

\section{Introduction}

Cannabis is the most used regulated substance in the world, and its consumption continues to increase, counting 183 million consumers [1]. Cannabinoid hyperemesis syndrome (CHS) is characterized by paroxysmal and recurrent episodes of nausea, vomiting and abdominal pain in chronic cannabis users described for the first time in 2004 by Allen et al. [2]. A cohort study by Habboushe et al. [3] in patients admitted to the emergency department observed that $32.9 \%$ of self-reported frequent marijuana users met a CHS definition. Symptomatic relief with hot water baths is a specific sign of this condition (91-92.3\% of cases) [2-4].

Several diagnostic criteria have been proposed (Allen et al., Sontineni et al., Simonetto et al., Pattathan et al., Sun et al., Cheung et al., Morris and Fisher) [2, 5-11]. Simonetto's criteria (2012) are the most consensual, we have summarized them in Table 1. More recently, other criteria have been proposed, namely Roma IV criteria for cannabinoid hyperemesis (2016) and Venkatesan's criteria (2019) [6].

\section{Case Report}

A 42-year-old previously healthy man was admitted several times to the emergency room within a 3-month period with complaints of generalized abdominal pain, epigastric region involuntary guarding, nausea and vomiting that improved with hot baths. During these admissions, he was examined by the internal medicine, gastroenterology and general surgery departments, undergoing several diagnostic exams (blood work, abdominal and thoracic X-ray, endoscopy and colonoscopy) that gave normal results. For symptomatic relief, several drugs were prescribed in ER: $40 \mathrm{mg}$ of esomeprazole; $10 \mathrm{mg} / 2 \mathrm{~mL}$ EV metoclopramide; $8 \mathrm{mg} / 4 \mathrm{ml} \mathrm{EV}$ of ondansetron and after discharge: $5 \mathrm{mg}$ of chlordiazepoxide +2.5 $\mathrm{mg}$ of clidinium bromide. Only partial and transient improvement was obtained, leading to frequent ER readmissions. To rule out a possible psychosomatic etiology, a psychiatric observation was requested. During the clinical interview, no other symptoms were reported and, at the examination, only mild anxious mood and naturalist (non-psychotic) beliefs were objectified. The patient reported a regular use of cannabinoid products (approximately $3 \mathrm{~g}$, 12 units per day, smoked, prepared from marijuana leaves), for more than 5 years, with a recent exacerbation of consumption sec-

Table 1. Diagnostic criteria for CHS (adapted from Simonetto et al. [6])

\begin{tabular}{|c|c|c|}
\hline \multirow{4}{*}{$\begin{array}{l}\text { Chronic cannabinoid } \\
\text { consumption ( }>1 \text { year) }\end{array}$} & Intense cyclic nausea and vomiting & Age $<50$ years \\
\hline & Resolution with suspension of consumption & Weight loss $>5 \mathrm{~kg}$ \\
\hline & Relief of symptoms with hot baths & Morning predominance of symptoms \\
\hline & Cannabinoid consumption weekly & $\begin{array}{l}\text { Negative results of complementary tests such as } \\
\text { laboratory, radiographic, endoscopic analysis }\end{array}$ \\
\hline
\end{tabular}




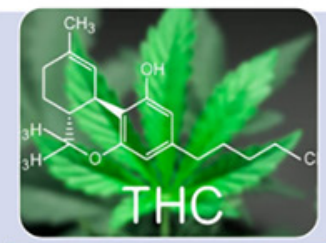

$\mathrm{CB} 1$ and $\mathrm{CB} 2$ agonist

Antiemetic Effect

Gastroparesis

TRPV1 channel

stimulation - emetic

threshold

High doses

desensitization CB1
CBO

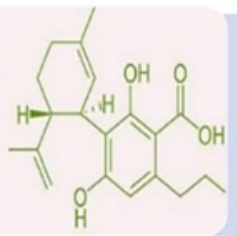

CB 1

CB1 agonist

Low doses - antiemetic effect

High doses - Proemetic effect

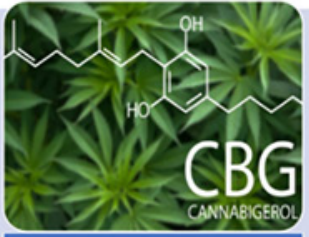

Reverses CBD antiemetic effect

\section{CYTOCHROME POLYMORPHISMS}

Accumulation in adipose tissue
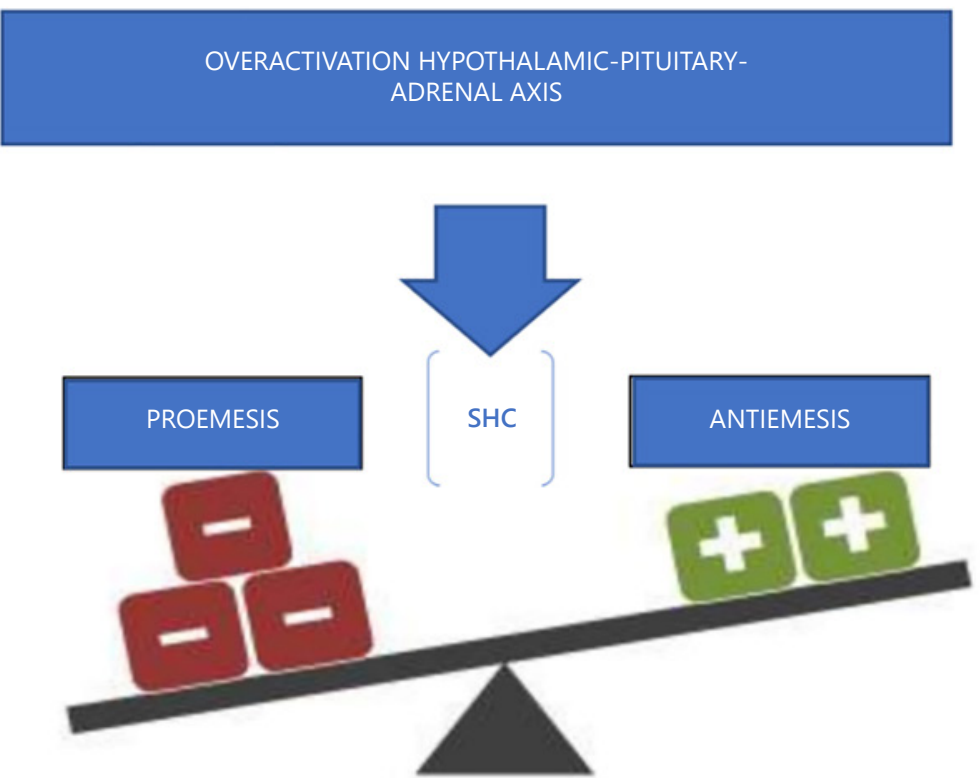

Fig. 1. Phatophysiologic mechanisms of CHS.

ondary to work-related stress. Due to the clinical history (onset of symptoms more than 6 months prior to observation, episodic vomiting, presentation after prolonged, excessive cannabis use and reliving of symptoms with hot baths), fair normality of the observation and the absence of major finds in the diagnostic exams performed, a working diagnosis of CHS was made. A brief psycho- education, explaining the risks associated with consumption and its relationship with the clinical symptoms was performed, leading to the cessation of cannabinoid use and a complete resolution of the symptoms in the following days. No new episodes were reported during the following year. 
Regarding the differential diagnosis, CHS shares sev-

Cannabinoids bind to cannabinoid receptors $\mathrm{CB} 1$ and CB2. CB1 are located in the central nervous system (CNS) and at nerve endings along the gastrointestinal system, modulating gastric secretion, motility and inflammation. CB2 are located in the lymphoid tissues and are involved in the regulation of the immune system. Activation of CB1 by endogenous cannabinoids results in inhibition of the hypothalamic-pituitary-adrenal axis (HPA) and the sympathetic nervous system response to stress stimuli.

The occurrence of CHS is somewhat paradoxical since the main psychoactive component of marijuana THC (tetrahydrocannabinol-9) is an effective antiemetic. The antiemetic effect results both from the activation of the CB1 receptors (central) and consequent non-competitive inhibition of 5HT3 serotonergic receptors (emetogenic), and the release of serotonin via pre-synaptic CB1 receptors. The CB1 activation in the medulla oblongata inhibits gastric motor function and proemetic dopamine activity in the CNS.

Several theories have been proposed to explain this paradoxical relationship, namely [12-17]: (1) accumulation of cannabinoids (THC) or their metabolites in the CNS and fat tissue; (2) extreme CB1 stimulation may desensitize the receptor; (3) role of other cannabinoids; (4) cytochrome $\mathrm{P} 450$ genetic polymorphisms, altering the metabolism of cannabinoids; and (5) deregulation of the normal functioning of the hypothalamic-pituitary-adrenal axis and the sympathetic nervous system in response to stress and disruption of the endocanabinoid system.

In summary, CHS probably results from the combination of factors described above that promote emesis (Fig. 1). CHS is usually divided into three phases, preemetic or prodromal (lasting for months or years - early nauseas, abdominal discomfort), hyperemetic (intense and persisting nausea, episodic vomiting, diffusing abdominal pain), and the recovery phase. CHS frequently implies recurrent evaluations in the emergency department as a result of difficulty in controlling vomiting, which leads to several complementary diagnostic tests. Nevertheless, most of the performed complementary diagnostic tests have unspecific results (laboratory tests may show hydroelectrolytic alterations and leukocytosis in the emetic phase), making differential diagnosis difficult. Patients are often subjected to various cycles of antiemetics with poor response and potential adverse effects. The main complications of CHS include renal failure, hydroelectrolytic disorders, esophageal injuries and pneumomediastinum [13].

Cannabinoid Hyperemesis Syndrome eral similarities with the cyclic vomiting syndrome and it can be hard to differentiate them. Both syndromes are characterized by cyclic stereotypic episodes of vomiting but, according to the Rome IV criteria, in CHS a chronic and excessive cannabis use is present and the relief of vomiting episodes is achieved by sustained cessation of its consumption [14].

The treatment in the acute phase (emetics) involves supportive measures (hydration, antiemetics, etc.), which are generally not very effective.

The evidence of pharmacological treatment is limited, with benzodiazepines being the drugs most reported to be effective in the acute treatment of CHS, followed by haloperidol and other antipsychotics. Topical capsaicin (in the form of a skin patch, transdermal patch or ointment), which works by promoting analgesia via inactivation and desensitization of sensory neurons, has showed promising results [15-17].

A systematic review by Richards et al. [16], with 63 eligible studies and a sample of 205 individuals, demonstrated that quality evidence for the treatment of CHS is limited. Studies with level of evidence V $(n=44)$, benzodiazepines, metoclopramide, haloperidol, ondansetron, morphine and capsaicin were identified as effective treatments in the acute phase and tricyclic antidepressants in the maintenance phase. Nevertheless, the only known effective treatment of basic pathology (CHS) is a complete suspension of cannabinoid consumption. Otherwise, the probability of recurrence is high $[18,19]$.

Research on this topic is at an early stage, lacking more robust scientific evidence for better diagnostic and therapeutic definition.

\section{Conclusions}

This is an illustrative case of a poorly reported clinical entity, despite having a probable significant and increasing prevalence. With this case report, we want to raise awareness in order that clinicians identify and properly manage these cases, avoiding multiple emergency department admissions and redundant complementary diagnostic exams.

There is an increasing prevalence of CHS which is correlated to the worldwide increasing use of cannabis. However, it is still a rare clinical entity that most clinicians are not aware of, resulting in underdiagnosing and late diagnosis. Cannabis consumption should be ruled out, especially in young patients with unexplained vomiting, to avoid overlooking CHS. 


\section{Statement of Ethics}

The study is in accordance with the instructions for the authors and with the ethical and legal principles (according to the Declaration of Helsinki by the World Medical Association). The patient has given his written informed consent to publish his case.

\section{Conflict of Interest Statement}

There are no conflicts of interest to declare.

\section{Funding Sources}

We did not have any kind of financial support.

\section{Author Contributions}

J.M.N. and I.F. contributed to the conception, design and writing of the manuscript and final approval of the version to be published. M.D. contributed by providing the clinical case, content review and ensuring that questions related to the accuracy or integrity of any part of the work were appropriately investigated and resolved.

\section{References}

1 United Nations Office on Drugs and Crime. World Drug Report 2016 [homepage na Internet]. United Nations Office on Drugs and Crime. World Drug Report, Inc.; c2016-05; [consultado $2020 \mathrm{Fev}$ 12]. Disponível em: https://www.unodc.org/doc/wdr2016/ WORLD_DRUG_REPORT_2016_web.pdf

2 Allen JH, de Moore GM, Heddle R, Twartz JC. Cannabinoid hyperemesis: cyclical hyperemesis in association with chronic cannabis abuse. Gut. 2004 Nov;53(11):1566-70.

3 Habboushe J, Rubin A, Liu H, Hoffman RS. The Prevalence of Cannabinoid Hyperemesis Syndrome Among Regular Marijuana Smokers in an Urban Public Hospital. Basic Clin Pharmacol Toxicol. 2018 Jun;122(6):660-2.

4 Sorensen CJ, DeSanto K, Borgelt L, Phillips KT, Monte AA. Cannabinoid hyperemesis syn-drome: diagnosis, pathophysiology, and treatment - a systematic review. J Med Toxicol. 2017 Mar;13(1):71-87.

5 Carla CN. Síndrome de hiperemesis cannabinoide: una nueva entidad clínica que afecta a consumidores de cannabis. Informaciones Psiquiátricas. 2016;226:31-49.

6 Venkatesan T, Levinthal DJ, Li BU, Tarbell SE, Adams KA, Issenman RM, et al. Role of chronic cannabis use: cyclic vomiting syndrome vs cannabinoid hyperemesis syndrome. Neurogastroenterol Motil. 2019 Jun; 31(S2 Suppl 2):e13606.
7 Sontineni SP, Chaudhary S, Sontineni V, Lanspa SJ. Cannabinoid hyperemesis syndrome: clinical diagnosis of an underrecognised manifestation of chronic cannabis abuse. World J Gastroenterol. 2009 Mar; 15(10):1264-6.

8 Simonetto DA, Oxentenko AS, Herman ML, Szostek JH. Cannabinoid hyperemesis: a case series of 98 patients. Mayo Clin Proc. 2012 Feb;87(2):114-9.

9 Pattathan MB, Hejazi RA, McCallum RW. Association of marijuana use and cyclic vomiting syndrome. Pharmaceuticals (Basel). 2012 Jun;5(7):719-26.

10 Sun S, Zimmermann AE. Cannabinoid hyperemesis syndrome. Hosp Pharm. 2013 Sep; 48(8):650-5.

11 Cheung E, Ng C, Foote J. A hot mess: a case of hyperemesis. Can Fam Physician. 2014 Jul; 60(7):633-7.

12 Schreck B, Wagneur N, Caillet P, Gérardin M, Cholet J, Spadari M, et al. Cannabinoid hyperemesis syndrome: review of the literature and of cases reported to the French addictovigilance network. Drug Alcohol Depend. 2018 Jan;182:27-32.
13 Richards JR. Cannabinoid Hyperemesis Syndrome: Pathophysiology and Treatment in the Emergency Department. J Emerg Med. 2018 Mar;54(3):354-63.

14 Morris R, Fisher M. Cannabinoid hyperemesis syndrome: a specific cause of cyclical vomiting. Int J Adolesc Med Health. 2014;26(1): 153-6.

15 Lapoint J, Meyer S, Yu CK, Koenig KL, Lev R Thihalolipavan S, et al. Cannabinoid Hyperemesis Syndrome: Public Health Implications and a Novel Model Treatment Guideline. West J Emerg Med. 2018 Mar;19(2):380-6.

16 Román F, Llorens P, Burillo-Putze G. Capsaicina tópica en el tratamiento del síndrome de hiperemesis por cannabinoides [Topical capsaicin cream in the treatment for cannabinoid hyperemesis syndrome]. Med Clin (Barc). 2016 Dec;147(11):517-8

17 Galli JA, Sawaya RA, Friedenberg FK. Cannabinoid hyperemesis syndrome. Curr Drug Abuse Rev. 2011 Dec;4(4):241-9.

18 Richards JR, Gordon BK, Danielson AR, Moulin AK. Pharmacologic Treatment of Cannabinoid Hyperemesis Syndrome: A Systematic Review. Pharmacotherapy. 2017 Jun; 37(6):725-34.

19 Torres F, Laveglia V, Molera C, Bonet M. Cannabinoid hyperemesis syndrome. An Pediatr (Barc). 2018 Nov;89(5):311-2. 